Louisiana State University

LSU Digital Commons

$9-1-2016$

\title{
Response to Blossey and Casagrande: ecological and evolutionary processes make host specificity at the subspecies level exceedingly unlikely
}

\author{
Ganesh P. Bhattarai \\ University of Florida Institute of Food and Agricultural Sciences \\ Warwick J. Allen \\ Louisiana State University \\ James T. Cronin \\ Louisiana State University \\ Erik Kiviat \\ Hudsonia Ltd \\ Laura A. Meyerson \\ University of Rhode Island
}

Follow this and additional works at: https://digitalcommons.Isu.edu/biosci_pubs

\begin{abstract}
Recommended Citation
Bhattarai, G., Allen, W., Cronin, J., Kiviat, E., \& Meyerson, L. (2016). Response to Blossey and Casagrande: ecological and evolutionary processes make host specificity at the subspecies level exceedingly unlikely. Biological Invasions, 18 (9), 2757-2758. https://doi.org/10.1007/s10530-016-1215-1
\end{abstract}

This Article is brought to you for free and open access by the Department of Biological Sciences at LSU Digital Commons. It has been accepted for inclusion in Faculty Publications by an authorized administrator of LSU Digital Commons. For more information, please contact ir@lsu.edu. 


\title{
Response to Blossey and Casagrande: ecological and evolutionary processes make host specificity at the subspecies level exceedingly unlikely
}

\author{
Ganesh P. Bhattarai • Warwick J. Allen • \\ James T. Cronin · Erik Kiviat • \\ Laura A. Meyerson
}

Received: 24 June 2016/Accepted: 27 June 2016/Published online: 4 July 2016

(C) Springer International Publishing Switzerland 2016

We agree with Blossey and Casagrande (2016) that absolute host-specificity is a necessity for successful biological control of invasive plants without unintended consequences for native species. However, inclusion of non-target native species in the diet of a biological control agent is a relatively common phenomenon with native congeners of the target plant species at greatest risk (Pemberton 2000). As our concerns relate to North American native and invasive Phragmites australis, and host-shifts at the subspecific level, the risk is substantially greater. We reiterate our previous arguments that the literature is replete with examples of how environmental context

Guest editors: Laura A. Meyerson and Kristin Saltonstall/ Phragmites invasion.

G. P. Bhattarai $(\bowtie)$

Indian River Research and Education Center, University

of Florida, Fort Pierce, FL 34945, USA

e-mail: bhattaraigp@gmail.com

\section{W. J. Allen · J. T. Cronin}

Department of Biological Sciences, Louisiana State

University, Baton Rouge, LA 70803, USA

E. Kiviat

Hudsonia Ltd, 30 Campus Road,

P.O. Box 5000, Annandale, NY 12504, USA

\section{A. Meyerson}

Natural Resources Science, University of Rhode Island, Kingston, RI 02881, USA (e.g., spillover effects, apparent competition, biogeographic variation in herbivore resistance) and evolution (e.g., via the hybrid bridge hypothesis) can lead to incorporation of new hosts into the diet. None of these possibilities were addressed by Blossey and Casagrande (2016), nor can they be in a simple laboratory/greenhouse study of host specificity.

Herbivore specificity for the invasive genotype is hardly as clear cut as Blossey and Casagrande (2016) claim. First, contrary to their claim, Lipara pullitarsis infests and successfully develops in native Phragmites (Allen et al. 2015). Second, another purported specialist, Lasioptera hungarica, attacks native-invasive hybrids (Saltonstall et al. 2014), a potential first step to a host shift (i.e., the hybrid bridge hypothesis). Finally, the noctuid moths (Archanara geminipuncta and Archanara neurica) they propose for biological control of invasive Phragmites in North America do not show the absolute host-specificity required to prevent damage to native genotypes. Fundamental host-ranges of these species include native genotypes of Phragmites and several other wetland grasses, including some economically important species (Blossey et al. 2013). Although leaf-sheaths, overwintering sites for Archanara eggs and larvae, "often" drop off from native stems, this is far from absolute and provides no assurance that native genotypes will not be attacked. Archanara also attack multiple stems during development, so can easily move to adjacent native Phragmites patches. Relying on managers to control 
herbivore spillover from invasive to native genotypes in perpetuity is wishful thinking. That this approach is even suggested constitutes clear acknowledgement by Blossey and Casagrande (2016) that sub-specific host specificity is not absolute, nor possible.

\section{References}

Allen WJ, Young RE, Bhattarai GP, Croy JR et al (2015) Multitrophic enemy escape of invasive Phragmites australis and its introduced herbivores in North America. Biol Invasions 17:3419-3432
Blossey B, Casagrande RA (2016) Biological control of invasive Phragmites may safeguard native Phragmites and increase wetland conservation values. Biol Invasions. doi:10.1007/s10530-016-1196-0

Blossey B, Casagrande RA, Tewksbury L, Hinz H et al (2013) Identifying, developing and releasing insect biocontrol agents for the management of Phragmites australis. ERDC/EL TN-13-3, U.S. Army Engineer Research and Development Center, Vicksburg

Pemberton RW (2000) Predictable risk to native plans in weed biological control. Oecologia 125:489-494

Saltonstall K, Castillo HE, Blossey B (2014) Confirmed field hybridization of native and introduced Phragmites australis (Poaceae) in North America. Am J Bot 101:211-215 